\title{
Measuring confessionality by the outcomes? : Islamic religious education in the Finnish school system
}

Kimanen, Anuleena

2016-09

Kimanen , A 2016 , ' Measuring confessionality by the outcomes? Islamic religious education in the Finnish school system ' , British Journal of Religious Education , vol. 38 , no. 3 , pp. 264-278 . https://doi.org/10.1080/01416200.2014.984582

http://hdl.handle.net/10138/300356

https://doi.org/10.1080/01416200.2014.984582

acceptedVersion

Downloaded from Helda, University of Helsinki institutional repository.

This is an electronic reprint of the original article.

This reprint may differ from the original in pagination and typographic detail.

Please cite the original version. 
Measuring Confessionality by the Outcomes?

Islamic Religious Education in the Finnish School System

Anuleena Kimanen

Department of Teacher Education, University of Helsinki, Finland

anuleena.kimanen@helsinki.fi

The author is a post-doctoral researcher who is presently working as a teacher of Lutheran religious education and a teacher consultant for religious education for the city of Espoo. 


\title{
Measuring Confessionality by the Outcomes?
}

\section{Islamic Religious Education in the Finnish School System}

\author{
Confessionality is a term which is seldom defined but often used. One of its \\ meanings is enhancing the religiosity of pupils. In Finland, pupils are provided \\ with religious education in their own religion. Does this produce more religious \\ young people than a neutral or multi-religious education would produce? \\ Interviews with 15-16-year-old Muslim pupils at three different Finnish \\ comprehensive schools are examined in order to answer this question. The \\ young Muslims themselves usually regarded their families as the most important \\ factor in their religious identity, although they also acknowledged and valued the \\ impact of school. For them, knowledge of Islam was an important asset. Some \\ peer group influence could also be detected, although the interviewees stressed \\ the fact that their faith was a matter of individual choice. Islamic religious \\ education certainly provides an arena for developing religious attitudes and \\ models of behaviour, but other factors determine whether these models are \\ received or not. The focus of defining the degree of confessionality should be \\ shifted from the outcomes to the process of teaching, and in particular the \\ question whether the religious education class can be seen as a safe space for \\ every pupil.
}

Keywords: confessionality; Islamic religious education; conversion

\section{Introduction}

In this article the impact of the school's religious education on the religiosity of young Muslims is considered. In Finland pupils in comprehensive school are entitled to religious education (henceforth $\mathrm{RE}$ ) in their own religion. The subject is aimed at benefitting the pupil rather than the religious community, and using school classes to gain active new members for a religious group would be regarded with suspicion. When the matter of making pupils more religious than they would be otherwise is publicly debated in Finland the term confessionality is used, although it is not usually 
specifically defined. As the term is widely used in international academic debate as well, the matter calls for more reflection.

When the position of RE in the secular state school system is discussed, 'confessional' often stands for RE that somehow increases the religious commitment of the pupils and 'non-confessional' for totally neutral (or secular) religious education, Finnish RE lies somewhere between the two. Religious communities only have a cooperative role, while educational authorities bear the responsibility and define the goals of young people's education. Finland has a national curriculum, and all the minority religions, 12 altogether, have certain common contents, such as a knowledge of Finnish religious history as well as other religions. No worship is to take place in the classes, although demonstrations and simulations are allowed, and prayers, for example, can be learnt by heart. The teacher should treat the pupils equally and avoid indoctrination (Board of Education 2006, 6; NCCO 2006; see also Kallioniemi and Ubani 2012, 179).

In the Finnish school system a pupil can receive education in his or her own religion if there are within the municipality at least three pupils whose parents request it and these parents belong to a registered religious community. When the instruction has already been started in the municipality, anybody whose cultural background matches the religion taught can join the classes. For those who do not observe any religion or whose religion is not taught within the municipality a non-religious class that deals with life questions and ethics is provided. Most pupils attend the classes in Lutheran religious education, which anyone can elect even if there is a class in his or her own religion available (Basic Education Act, amendment 454/2003). In 2010 almost 3\% of the pupils opted for the secular ethics classes, some $1 \%$ for the Orthodox classes and 1.6\% for other religions (Statistics Finland 2011). Orthodox Christians form a historical 
minority in Finland, which is probably why their proportion is presented separately. The majority of pupils who observe another religion are Muslims, while Roman Catholics represent a significantly smaller group, and other religions are marginal. These religions are taught almost exclusively in the largest Finnish cities (Board of Education 2009).

One question often arises: If religious education is given in separate groups for different denominations, is it done in order to socialise the pupils into a certain religious way of life? That would not be in accordance with the liberal education values. There is some tension between liberal and Islamic education principles. (Rissanen 2014, 20-32.) On these grounds a study of the impact of schools' religious education on the identity of young Muslims is highly relevant.

\section{Defining the Degree of Confessionality}

The Finnish RE system presented above was described on the level of legislation and other authoritative documents. However, there are more levels to be taken into account if one wants to understand the nature of RE within a certain system. In this analysis I loosely follow the model of school didactics provided by Michael Uljens (1997, 64-67).

Picture 1. Uljens 1997, 45

The second level after the intentions of the collective level is planning by (and intentions of) the teacher which involves the interpretation of the laws and syllabi. Also the authors of the textbooks interpret the syllabi, but it is, however, the teacher who selects the material to be used at the third level, the interaction between the teacher and the group of pupils. Apart from texts, the teacher also selects the teaching methods. The pupils, for their part, bring their attitudes and life histories to the classroom. Thus, the 
atmosphere of the class and the pupils' perception of which values or attitudes they are supposed to adopt depends on many factors.

The last level consists of the outcomes (derived from Uljens's evaluation) of the RE classes and this relates to whether the pupils become more committed to religion than they would be otherwise. This article focuses on this last level and the question whether or not it is a good way to measure the confessionality of RE in a certain time or place. It is very difficult to separate the impact of the school's RE from the effects of other social environments and psychological processes. Religiosity or one's relation to religion is formed both in primary and secondary socialisation (Otterbeck 2010, 178).

The research question here could be put as follows: "What is the impact of the school's Islamic religious education (hence IRE) on the religious commitment of some young Muslims as evaluated by the pupils themselves?" Although the school's RE is not the only factor, it is the one that society is responsible for and is capable of adjusting.

\section{Muslim Youth in the School System}

Some scholars have brought up issues that might be linked with the school's IRE. Tuula Sakaranaho has expressed a concern that the Finnish model enforces religiosity among immigrants by forcing parents to choose sides (as there is no genuinely neutral option) and by providing an occasion for religiously active people to spread their attitude toward religion in schools (Sakaranaho 2006, 403, 424, 372; Sakaranaho 2008, 175176). According to a study among Kosovan immigrants in Finland, many women felt that many young men had adopted conservative attitudes toward the role of women after these men had been in contact with Muslims from other nationalities (Säävälä 2008, 121, 126, 127). Although IRE classes in Finnish schools are not mentioned in Säävälä’s 
study, they are obviously an important setting in which young Muslims are brought together.

The question "What goes on in IRE classes in Europe?" has been asked in some earlier studies. Jenny Berglund (2009) has studied IRE in three Muslim schools in Sweden from the point of view of the teacher. In these schools the lessons were given in Swedish and the backgrounds of the pupils were diverse, so the situation in many ways resembled the one experienced by Finnish IRE teachers. According to the study, translation of Islam would be a more appropriate term than transmission because a religion is not a static entity that can be transmitted as such from one generation to another but is adjusted to local circumstances.

In Finland Inkeri Rissanen (2013) has observed an IRE class where the teacher both emphasised the student's freedom of choice and wished to provide an understanding of what it is like to be an active member of the religious community. Harriet Zilliacus (Zilliacus \& Holm, 2013) interviewed both teachers and pupils of many minority religions about their RE classes. The pupils were for the most part happy about the classes but especially pupils with weak or mixed religious affiliation often felt uneasy. This was also reflected in the teachers' views. Teachers presupposed a strong affiliation in their classes, praised religious activity, and were confused when facing pupils with weak religious identity.

Various studies have established that the significance of religion often changes after migrating to another country. For many Muslim immigrants Islam is seen as a link to the home culture and provides a source of authority when bringing up children, the mosque community becoming a place of security and support. However, it is also possible that religion loses its central position in life when one lives in a secularised culture (Tiilikainen 2003, 135-136; Alitolppa-Niitamo 2004, 5). Especially those who 
have fled a religious regime are not likely to have an intensified religious identity. Though for some second-generation immigrants Islam may solve certain identity problems, others may not find the religiosity of their parents stamped by local homeland traditions of value in the host country. They may, for example, seek out a "pure" Islam, finding more information on the internet than from their mosque community or family (Ramji 2007; Beyer 2007; Jacobsen 2011).

In Britain a decrease in religious practice among second-generation immigrants has been reported as well as the emergence of criticism of traditional Islamic orthodoxy (Woodward 1996, 161-164; Sahin 2005, 178). Otterbeck (2010) has aimed to give a voice to 'less committed' young Muslims as opposed to the image of Islam as monolithic and non-compromising which prevails in the West. In any case, a secondgeneration Muslim immigrant has much to do in constructing his or her cultural identity, and religion plays an important part in this process (see also Brömssen 2003, 143-229).

\section{Research procedures}

This article is based on a small study in which seven Muslim teenagers attending IRE classes in Espoo were interviewed. The aim of the semi-structured interview was to explore whether in their view religious education had any empowering impact on them. Religious identity was thus one of the themes of the interview. The data was analysed using interpretive analysis (Hatch 2002, 179-191), i.e. impressions were identified and interpreted, followed by a review of the interpretations when rereading the data.

Espoo is the second largest city in Finland and it is located within the capital region. In 2010, when the interviews were carried out, there were over 800 Muslim 
pupils attending Islamic religious education classes at school, and five full-time teachers. The language of the classes is Finnish although vital terms and verses are learnt in Arabic. Where schools are near each other and there are only a few Muslim pupils, groups are combined. Islam is considered as one religion so there are no separate groups for Shia and Sunni Muslims, which nowadays is a national solution in Finnish schools (e-mail from a local school administrator Pia Jussila, 21October, 2011, and a national school administrator Pekka Iivonen, 7 April, 2011.)

The seven interviewed pupils represented six different nationalities: Kosovan, Somali, Iraqi, Kurdish, Iranian and Afghan. There were four girls and three boys, who were about to finish comprehensive school in one or two years. All of them could be described as second-generation immigrants for they had either been born in Finland or had immigrated before adolescence (Ramji 2007, 197). They were from three different schools, two of which had many Muslim pupils and one less than five. My requirement was that they had attended the IRE classes at least from the $5^{\text {th }}$ grade.

It became apparent that these seven volunteer participants had very similar, positive attitudes toward Islam, their school's religious education, and to Finnish society. Thus, this study does not claim to present the range of potential feelings that Muslim teenagers in Finland have about IRE, although it does provide a certain degree of insight into well-integrated young Muslims' thoughts. One can also integrate these findings with those of previous research (e. g. Rissanen 2013) to suggest that these positive attitudes do not merely represent the opinions of only a small minority.

A number of issues concerning religious identity were raised by the interviews. The first area of interest concerns the sources of identity, e. g. the most important reference groups. Second, the interviewees' relationship to the contents of the IRE is analysed. Third, the reactions of the interviewees to the idea that there should be a 
common RE subject for all instead of Islamic RE for Muslims only is investigated. Fourth, the impact of the IRE class peer group is discussed.

\section{Results}

\section{The reference groups of young Muslims}

Besides the IRE class, there are many other groups that a young Muslim belongs to. Understanding the meaning of these groups for them is needed when determining the possible advocates of faith and the social context of the conversion. The importance of the family was stressed by the interviewees on many occasions. The mosque community was not mentioned very often, though I did not enquire about it specifically. The peer group was not considered to be an important factor in their religiosity by most of the young Muslims. The relationship to the dominant religious (or in fact secularised) group was not seen as problematic and the young Muslims seemed to feel quite secure in their minority position. There were thus many factors that formed a favourable context for an Islamic reversion.

Five of the seven pupils named their family as the most important factor in their Muslim identity. One of these interviewees, however, later described how he had experienced a religious revival as a direct result of the IRE classes. Possibly this revival had reinforced his identification with the worldview of his parents or he felt that it was his duty to consider his family to be the most important source of his religious identity.

Parents represented a strong authority for the interviewees. One of the interviewees, for example, said that she could not marry anybody against the wishes of her parents. The interviewees expressed an appreciation for the teaching and advice they 
had received from their parents. There seemed to be considerable emotional warmth in the relations between the young Muslims and their families. One girl, for instance, mentioned that her uncles had recommended that she should attend daily prayers, but she emphasised that it had not been said in an authoritarian way.

Three of the interviewees mentioned their mosque community, and in all these cases the responses were significant. One of them referred to the mosque when talking about arguing with peers about what is right and wrong according to Islam. He said that if the other pupils do not believe him, they can ask more experienced Muslims in the mosque and find out that he was right. Another mentioned a female teacher at the mosque and her style of encouraging young people to interrupt and ask questions. The third was a girl who had spoken up in the mosque and had criticised the imams about things (apparently harsh punishments) that she and her family disapproved of. The incident was not a source of conflict between the imams and the girl's family, the imams were simply wondering about the episode. The mosque thus appeared to be both a source of authoritative knowledge and a place where thought could be freely expressed.

Two of the interviewees compared the importance of religious and national identity. For both Muslim identity came before national identity, and according to one of them living in exile affected the situation. Recognising this shows that at least for this informant being a Muslim was probably more important than it would be in other circumstances.

Two of the seven participants reported that almost all their friends were Muslim, while the others had either non-Muslim or a mixed circle of friends. Of the two who had exclusively Muslim friends only one said that the peer group represented an important source of religious identity. The rest of the group interviewed did not discuss religion 
much among their friends. Having non-Muslim friends did not prevent the Muslim pupils from being active Muslims, although some of them were more passive than others.

Being a member of a religious minority was not a problem to most of the interviewees. Only two reported that they had experienced islamophobia or racism, and some did not seem to have reflected on the issue very much. I have translated the interview extracts from the original Finnish.

Interviewee 3: Well, I mean, in Finland being a Muslim is easy. It's not like difficult and you've not got to be ashamed or be like embarrassed or shy about your own religion, but here it's totally ... I am very satisfied that I can be [open about my religion?] here. In some countries you can't.

One of the interviewees also brought up the benefit of getting to know about other religions, which would be more difficult to do in a country with a Muslim majority. Living in a multireligious country was thus seen in a positive light by these secondgeneration immigrants. They were also confident that this non-problematic situation would continue in their future as well. It is possible that this positive attitude also maed them ready to participate the study (cf Berglund 2013, 213).

\section{Views on the contents of the education}

Apart from the contents common to all RE subjects, the IRE curriculum consists of the history of Islam, Islamic culture, Islamic ethics and rituals, the Quran and the hadith tradition (NCCO 2006). It has been pointed out by many researchers that the curricula in the minority religions are more confessional than in the majority Lutheran religious education (e. g. Sakaranaho 2006, 169-170). This means that these curricula are more 
comprehensive in explaining the rituals and the dogmas and dedicate less time to world religions than the Lutheran curriculum. Although the contents of the lessons are not the main focus of this article, interviewees' views on lesson content must be addressed in order to find out whether or not they saw the interaction between the teacher and the pupils as a factor of their religiosity.

In responding to the questions how IRE classes had influenced their religious identity, only one respondent mentioned the teaching of religious attitudes:

I3: The instruction at school tells you that wherever you are, your own religion is important. It is not good idea to give up religion even if you live in another country.

All the others referred to the knowledge of Islam that they had received. It is probably natural that teenage pupils think that the main task of any school subject is to provide information. However, knowledge was valued by these young Muslim pupils in many ways. For instance, knowledge was regarded as a source of authority, and the fact that the school's IRE made the pupils' knowledge more uniform was recognised as an important feature. Thus the contents of IRE were not only considered to be things that are merely interesting to know, they were felt to be significant in their social relationships, too.

When discussing further the notion of knowledge, it was clearly important for the young Muslims interviewed to know the grounds of the Muslim way of life. One reason for this came up in the interviews and was connected to their minority status. Many of the interviewees had faced situations where they were asked questions about the reasons for their Muslim customs. For some, having to answer questions was a factor which launched their personal religious commitment (cf. Jacobsen 2001, 305). In 
the interviews conducted for this study the personal need to make sense of the Muslim way of life seemed to be the most important reason to seek knowledge..

Concerning the role of the school's IRE in shaping the religious identity of a Muslim pupil, many would like to distinguish between whether the pupils had developed a need for knowledge about the Muslim way of life outside of school or whether they were persuaded by knowledge acquired at school to become practising Muslims. However, there are reasons to reformulate the question altogether. First, there probably is constant interaction between the personal and the social factors (see also Rambo 1993).

R: What about Islamic religious education at school?

I7: It has been an influence too, because there are some things that I have not known so the school's teacher told us. ... I've read books and stuff more than my parents have told me. But the teacher has explained many things and taught us many things about Islam.

R: Well, does it increase knowledge or strengthen the faith?

I7 (without hesitation): It increases knowledge.

Just before this statement the informant stated that her parents had influenced most her Muslim identity. Her family, her own initiative to read books, and the impulses given by the IRE classes seemingly fed each other. Second, Jacobsen $(2011,44-45)$ argues that instead of a dichotomisation of 'individual choice' and 'unreflective conformity' it would be more interesting to explore the kinds of subjectivities that are formed and how individuals see their relation towards their community. In the citation above the interviewee explicitly emphasises her own independence and claims that the IRE classes only provide information. That was how she wanted to position herself.

The case above illustrates well how difficult it is to distinguish the influence of different factors or define an independent religious interest, and this will be discussed 
further later on. What is to be observed here are the various meanings and uses of a knowledge of Islam: the capability of answering non-Muslims' questions, solving disputes among Muslims, authority and shaping one's own identity.

\section{Different models of $R E$ - weighing the options}

What, then, is the significance of the fact that IRE classes bring young Muslims together? To answer these questions, I briefly described to the interviewees a different model of multi-religious RE and asked what they thought of it. Most of them expressed positive attitudes towards this option.

Only two preferred the present model of RE, but they also pointed out some benefits of RE attended by everyone. The reason for their preference was that the information on religions could easily become confusing. Those who favoured the multireligious model for their part argued that it would be interesting to hear more about other faiths. One pointed out that it is a duty mentioned in the Quran to learn more about other religions. Another noted that they had already learnt about other faiths in the IRE classes. One interviewee who had experienced racism believed (when specifically asked) that common RE classes would diminish islamophobia. Still, it must be emphasised that in other contexts many of the interviewees praised the opportunity to learn more about their own religion at school, and they regarded it as a sign from Finnish society that Islam is accepted as a religion.

In fact, it is not surprising that the interviewed Muslim pupils felt so positively about non-Islamic religious education. It would mean that they learnt RE with their own classes, as they did with the majority of other subjects. Most of the interviewees were pupils in schools where Muslims represented a rather large minority, so they would not 
be alone in an RE lesson. The only interviewee from a school with only three Muslim pupils felt that the other pupils in his group simply prevented him from learning more. Although young people share the same religious background, it is not self-evident that they feel a sense of being bonded.

\section{The significance of the peer group}

Previous research has brought up the question whether Islamic religious education puts pressure on pupils to follow a certain kind of Islam (Sakaranaho 2008, Säävälä 2008). In the interviews the contents of IRE were discussed, and it was mentioned by the interviewees themselves that the teacher provides the pupils with the 'right' knowledge and that they also learn from each other. However, although the pupils seldom mentioned their friends and schoolmates as contributors to their religious identity, there seemed to be more influence than was acknowledged.

One of the interviewees gave this report on the help given by other Muslim pupils when answering questions by non-Muslims:

I7: I've been asking that, for instance, why just that way and why you've got to fast and... And my pals have told me that it's because this is for us, like, that you've got to fast. Then they have told me more than... the teacher hasn't been able to answer all the questions that people keep asking, so it's nice that my friends have also explained.

Various meanings can be detected here. She probably means that other young Muslims are more capable of answering the questions of young people than the teacher. They possibly understand what the questions are about and what kinds of answers are intelligible to young people. At the same time, she reveals that she herself has been wondering why Muslims fast. No doubt the issue had been dealt with by the teacher, 
too, but the fact that her peers expressed support for the practice gave it even greater credibility and acceptability.

Another case worth analysing is related to the use of scarves. Only one of the four interviewed girls wore a headscarf. She mentioned that sometimes the boys in the IRE group ask the girls why they do not cover their heads. The words that the interviewee used in this connection were "giving hints" and "persuading us to use scarves". She was also convinced that the girls would not be offended by these suggestions. The two other girls from this group did not mention anything about the behaviour of the boys. Either they did not want to tell an outsider about conflicts or they did not object to the boys' questions.

Somebody might be tempted to see here an example of gender hierarchy. I would like to point out two other but intertwined explanations in this case. Earlier a similar case was mentioned when a girl was not offended by her uncles recommending her to pray daily. It would seem to me that these young Muslims did not object to others showing them 'the right way'. Second, in the interviews two girls seemed to think of the Islamic way of life as something that they would follow eventually in the indefinite future. This could be seen in expressions like "if I decide to go in for the scarf when I grow up (I1)" and "I am not as much of a Muslim yet (I7)". Also, the girl who reported about the scarf issue in the IRE class told me that the girls' answer to the boys is "I' $m$ not ready yet". This attitude that full observation of Islamic rules is something for adults with a family has been also been observed by Vertovec $(1998,99-100)$ and Otterbeck $(2010,71,78,169-172)$. Jacobsen's $(2011,310)$ informants also had the conception that before one can start wearing the hijab, one has to have certain moral qualities and also be ready to face the prejudices of non-Muslims. 
Whatever the influence of the peer group or the family was, the interviewees wanted to express the notion that their religiosity was free, independent and personal.

I2: Well I do quite personally believe in every single thing there.

I7: I believe myself for I've read books and watched everything... related to Islam on television.

I3: (when discussing questions from non-Muslims) (...) why you've got a scarf and someone else hasn't. I say that God asked us but we mustn't be forced to do anything. It's forbidden in our religion.

A similar tendency has been perceived in many other studies among immigrant Muslims from early adolescence to early adulthood (Brömssen 2003, 150; Ramji 2007, 204; Berglund 2013, 211). It can be argued for with the help of the Islamic concept niyya, intention, without which any conforming with the rules is worthless. Otterbeck considers that this sort of tendency towards individual choice may be the consequence of the secularised environment or simultaneously the impact of modern Islamic theology (Otterbeck 2010, 65, 197). Jacobsen $(2011,225-232)$ sees it as a part of a world-wide process in which also growing literacy, education and mass media make Muslims more conscious and cause debate about their beliefs and practices.

\section{Conclusion}

The interviews with seven second-generation young Muslims show that IRE within the Finnish school system has the capacity to enhance their religiosity to some extent, but there are many other factors as well. They themselves stress the importance of their families and their own interest and commitment. Many of them have other sources of knowledge about Islam apart from the family and school. 
Following the Uljens' model, we have seen that the collective intentions, especially the IRE curriculum, put a lot of weight on knowing the rituals and the dogmas. As to the teachers' intentions, previous research shows that they consider their duty to be to enhance religious commitment and the ability to follow the Islamic way of life, though this should also involve critical thinking and tolerance (Lempinen 2007, 239-245; Zilliacus 2013). The pupils, on the other hand, experienced that teachers primarily gave them knowledge about Islam. Knowledge, on the other hand, was important for them becoming active members of the Muslim community. This, among other features mentioned above, indicates that many of them brought their own needs to gain readiness to become practicing Muslims into the classroom, the interaction stage of the Uljens' model.

These young Finnish Muslims can be compared with the only slightly older Swedish and Danish Muslims interviewed by Jonas Otterbeck. Otterbeck wanted to give a voice to less committed Muslims. Most of them, however, simply did not follow the Islamic way of life as closely as they knew they should (Otterbeck 2010, 15-16, 71, 116-117, 145). Some of my informants had a similar position. An important difference between them is their familiarity with Islam and its various forms. The Swedish and Danish young Muslims, not having had systematic Islamic religious education at school or elsewhere, often had a fragmented knowledge of Islam influenced by family tradition (Otterbeck, 2010, 118, 131). The Finnish Muslim pupils, on the other hand, expressed satisfaction about having access to a range of Islamic traditions.

The last phase of the adopted Uljens' model was the outcomes. Previous research shows that instead of growing more religious, pupils with a weak or mixed religious background are likely to feel themselves to be outsiders within the group and want to switch to the ethics class (Zilliacus \& Holm 2013). This strengthens the picture 
that religious commitment cannot result from the RE classes alone. It is, nonetheless, problematic if an IRE class is not a safe place for everyone. This study has shown that some Muslim youth require further knowledge and advice on the Islamic way of life, so abolishing the IRE classes would no doubt have an adverse effect on them. In further studies it would be important to address pupils who feel uneasy in RE classes and find ways to mitigate this feeling.

With all this in mind, it seems that it is not sufficient to define the degree of confessionality by observing the last level of the process, the outcomes of the education given. The religious commitment of pupils is part of the picture, but it is an element that is not fully within the control of the school. If pupils become active members of a religious community as a result of the school's RE, they probably also have a social or psychological background which favours religion. If not, they are likely to lose interest after having finished school. Instead, the level of enhancing commitment should be defined more by the earlier level, by the interaction in the classroom. It is clear that in this field of investigation much remains to be discovered.

\section{References}

Alitolppa-Niitamo, A. 2004. "The Somali Diaspora in Finland: Changes, Challenges and Dreams.” In The Ice-Breakers. Helsinki: Väestöntutkimuslaitos.

Basic Education Act, amendment 454/2003.

Berglund, J. 2009. Teaching Islam: Islamic Religious Education at Three Muslim Schools in Sweden. Uppsala universitet.

Berglund, J. 2013. "Islamic identity and its role in the lives of young Swedish Muslims" Contemporary Islam 7, 207-227.

Beyer, P. 2007. "Can the Tail Wag the Dog? Diaspora Reconstructions of Religions in a Globalized Society. " Nordic Journal of Religion and Society 20 (1): 41-63.

Board of Education. 2006. Muistio: Perusopetuslain muutoksen vaikutukset uskonnon ja elämänkatsomustiedon opetukseen sekä koulun toimintaan [Memorandum: 
The Effects of the Change in the Basic Education Act on Religious Education and Ethics Classes and School Activities] edu.fi/download/130016_Tiedote_19_2006.pdf

Board of Education. 2009: Muistio perusopetuksen yleisten tavoitteiden ja tuntijaon työryhmälle: Uskonto [Memorandum for the committee of distribution of lesson hours: Religious Education] http://www.oph.fi/download/118443_Uskonnon_muistio_tyoryhmalle_1612200 9.pdf

Brömssen, K. v. 2003. Tolkningar, förhandlingar och tystnader. Elevers tal om religion I det mångkulturella och postkoloniala rummet. Göteborg: Universitas Gothoburgensis.

Hatch, J. A. 2002. Doing Qualitative Research in Education Settings. State University of New York Press.

Jacobsen, C. 2011. Islamic Traditions and Muslim Youth in Norway. Leiden: Brill.

Kallioniemi, A \& Ubani, M. 2012. "Religious Education in Finnish School System." In Miracle of Education: The Principles and Practices of Teaching and Learning in Finnish Schools edited by H. Niemi, A. Toom and A. Kallioniemi. Rotterdam: Sense Publishers.

Lempinen, H. 2007. "Peruskoulun islaminopetuksen tavoitteet ja haasteet: Opettajien näkökulma." In Monikulttuurisuus ja uudistuva katsomusaineiden opetus, edited by T. Sakaranaho and A. Jamisto, 239-250. Helsingin yliopisto.

NCCO (National core curriculum for other religions within basic education). 2006. Helsinki: Board of Education.

Otterbeck, J. 2010. Samtidsislam: Unga Muslimer i Malmö och Köpenhamn. Stockholm: Carlsson Bokförlag.

Rambo, L. R. 1993. Understanding Religious Conversion. Yale University Press.

Ramji, R. 2007. "Being Muslim and Being Canadian: How Second Generation Muslim Women Create Religious Identities in Two Worlds. "In Women and Religion in the West: Challenging Secularization edited by K. Aune, S. Sharma and G. Vincett, 195-206. Farnham: Ashgate.

Rissanen, I. 2013. "Developing Religious Identities of Muslim Students in the Classroom: A Case Study from Finland.” British Journal of Religious Education. DOI: 10.1080/01416200.2013.773194. 
Rissanen, I. 2014. Negotiating Identity and Tradition in Single-faith Religious Education: A Case Study of Islamic Religious Education in Finnish Schools. Münster: Waxmann.

Säävälä, M. 2008. "Islam Kosovosta Suomeen muutaneiden naisten elämässä. ” In Islam Suomessa: Muslimit arjessa, mediassa ja yhteiskunnassa edited by T. Martikainen, T. Sakaranaho and M. Juntunen, 111-131. Helsinki: SKS.

Sahin, A. 2005. "Exploring the Religious Life-World and Attitude toward Islam among British Muslim Adolescents." In Religion, Education and Adolescence: International Empirical Perspectives edited by L. J. Francis, M. Robbins and J. Astley 164-184. Cardiff: University of Wales Press.

Sakaranaho, T. 2006. Religious Freedom, Multiculturalism, islam: Cross-reading Finland and Ireland. Leiden: Brill.

Sakaranaho, T. 2008. "Islam ja muuttuva katsomusaineiden opetus koulussa. ” In Islam Suomessa: Muslimit arjessa, mediassa ja yhteiskunnassa edited by T. Martikainen, T. Sakaranaho and M. Juntunen, 157-181. Helsinki: SKS.

Statistics Finland. 2011. Education: Subject Choices of Students 2010. Helsinki: Statistics Finland.

Tiilikainen, M. 2003. Arjen islam: Somalinaisten elämää Suomessa. Tampere: Vastapaino.

Uljens, M. 1997. School Didactics and Learning: A School Didactic Model Framing an Analysis of Pedagogical Implications of Learning Theory. Hove: Psychology Press.

Vertovec, S. 1998. "Young Muslims in Keighley, West Yorkshire: Cultural Identity, Context and 'Community'.” In Muslim European Youth: Reproducing Ethinicity, Religion, Culture edited by S. Vertovec \& A. Rogers, 87-101. Aldershot: Ashgate.

Woodward, P. 1996. "Orthodoxy and Openness: The Experiences of Muslim Children." In Freedom and Authority in Religions and Religious Education edited by B. Gates, 155-164. London: Cassell.

Zilliacus, H. \&. Holm G. 2013. “'We have our own religion': A Pupil Perspective on Minority Religion and Ethics Instruction in Finland." British Journal of Religious Education. DOI: 10.1080/01416200.2012.750707.

Zilliacus, H. 2013. “Addressing religious plurality - a Teacher perspective on minority religion and secular ethics education." Intercultural Education 24:6, 507-520. 
